\title{
OIL AND GAS CONSERVATION IN SASKATCHEWAN
}

\author{
J. T. CAWLEY*
}

The unrestricted application of the rule of capture in the oil and gas industry results in wasteful practices. The author discusses how the Saskatchewan Oil and Gas Conservation Act attempts to solve these difficulties and thereby provide optimum efficiency and also enable each common owner to obtain a just and equitable share of the total production of any pool.

\section{Philosophy Behind Oil and Gas Conservation Legislation}

With the development of oil and gas resources in Saskatchewan in the early fifties, the Government of Saskatchewan, like many other jurisdictions in Canada and the United States, realized the wasteful practices that could result from the indiscriminate application of the rule of capture in the oil and gas industry. Because of the impossibility of identifying the particular oil or gas that is produced from a well with the land under which the oil and gas might have been located originally, the common law courts established many years ago the principle that the mineral owner of a tract has the right to drill wells on it, and that he owns the oil and gas produced from his wells, even though such oil and gas might be drained from under his neighbor's land. This principle, known as the rule of capture, had been applied to the ownership of wild birds and animals, that is, title to wild birds and animals belonged to the man who has the right to capture them and who has in fact captured them.

The migratory nature of oil and gas without regard to lease or ownership boundaries meant, therefore, that the adjoining mineral owner or lessee had to drill wells on his tract to gain possession of the oil or gas underlying his tract, and to prevent the adverse effects of drainage unto adjacent lands. This resulted in a competitive and unrestricted race to see who could drill the most wells and produce from a common source of supply, such as an oil pool, at the highest capacity and at the fastest rate.

Thus, under the rule of capture, it was always a frantic race against time and against the other fellow. However, such uncontrolled development and rapid and often wasteful production without regard to prudent and proper operation and sound engineering practices result in premature depletion of pools, loss of oil and gas, unnecessary or excessive drilling and production costs, over-production and waste. For instance, physical waste is created through the inefficient use in the reservoir of natural energy that may be available to move the oil or gas to the well bore.

Sound scientific and engineering principles and practices dictate, therefore, that effective control and maintenance of reservoir pressure in an oil or gas producing formation by controlled production rates is a basic means of obtaining maximum primary recovery. Pressure maintenance helps to prevent the loss of petroleum mobility which allows the oil or gas to flow more easily through the formation and tends to

- Deputy Minister of Mineral Resources, Province of Saskatchewan, and Chairman Saskatchewan Oil and Gas Conservation Board. This paper is the text of a speech delivered to the Canadian Petroleum Law Foundation. Seventh Annual Research Seminar in Oil and Gas Law, Jasper, Alberta, May 29 to June 1, 1968. 
eliminate, though not entirely, uneven encroachment and by-passing of oil and gas in the underground reservoir.

Moreover, in order to prevent the migration of oil or gas across arbitrary surface survey lines, under the rule of capture, mineral owners and lessees drilled wells near the surface boundary lines without regard to proper spacing for maximum recovery or economic efficiency of operation, or to market demand, adequate storage or marketing facilities. Furthermore, under the antiquated rule of capture, which was merely a rule of convenience adopted by the courts at a time when little was known of the underground character and behavior of oil and gas and when it was impossible to determine the ultimate source of the oil and gas produced by a well, the wasteful acts of an operator interfered with the property rights of others who had shares in the production from the same pool.

Under these circumstances, therefore, the application of the rule of capture, indiscriminate and uncontrolled production operations and wasteful practices had to be considered and regulated. Individual operators and mineral owners were unable to institute effective conservation measures by voluntary co-operative action. Consequently, it was left to the government to introduce the necessary conservation legislation and to create an administrative agency to regulate operations in order to prevent waste in the production of oil and gas and also for the protection of property rights in a common pool that may be affected by such production and its regulation.

An Oil and Gas Conservation Act will have to recognize the following principles if it is to be effective for the conservation of oil and gas:

(1) The oil pool rather than the individual tract or lease is the natural competitive unit in the oil and gas business and all planning and development should be on this basis;

(2) In financing new development projects there should be an emphasis on consolidation of tracts rather than the buying of divided interests or spreads of acreage;

(3) No new drilling projects should be undertaken in a checker-boarded area until every reasonable effort has been made to effect a common agreement for development, even though this may mean a slight delay in terms of time in initiating the project;

(4) To effectively direct the project in toto, it is essential that a policy be adopted among the competing companies of revealing to each prospective member of a co-ordinated development the geological information, including the results of core drilling;

(5) In order to promote conservation and the movement towards conservation, it is of the very greatest importance that the executives of a company see to it that the land departments are so instructed that they always recognize the ultimate objective of conservation and the development of properties as a unitized entity;

(6) Legal departments of each company must take a liberal view with respect to contractual terms so that delay will be avoided in the movement towards full conservation objectives.

The regulatory agencies must be constantly making improvements in the application of general conservation principles. Generally speaking, the regulatory agent must consider:

(1) Orderly spacing patterns geared to a reasonable knowledge of the reservoir conditions expected to prevail;

(2) In the early development of a pool the restriction of allowables until the producing factors are reasonably determined;

(3) Constant appraisal towards the ultimate objective of producing the pool as a unit; 
(4) Restriction of oil production rates in water drive reservoirs to near the rate at which the water encroaches in order to utilize the energy available most effectively;

(5) Restriction of oil production in fields with high gas-oil ratios and ordering re-injection of the gas, or the conservation and utilization of the gas;

(6) Restriction of oil production in reservoirs with gas caps to a rate at which the gas cap encroaches on the oil zone;

(7) Restriction on producing gas-oil ratios and water-oil ratios to prevent water-coning or gas-coning and thus bypassing of oil, particularly in reservoirs where there is an active water drive;

(8) Efficient control of completion practices to prevent the loss of oil and gas through blow-outs and inefficient completions;

(9) In addition to the general engineering restrictions listed above, the industry, in relation to maintaining good public relations and protecting the correlative rights of other interested parties, is required to protect the surface and the fresh water supplies of the general public affected by the exploitation of oil and gas resources.

\section{The Oil and Gas Conservation Act and Regulations}

In the Province of Saskatchewan the governing legislation is the Oil and Gas Conservation Act and regulations made thereunder.' The administrative agency is the Department of Mineral Resources over which the Minister of Mineral Resources presides. The Minister has jurisdiction and authority over all persons and property, public and private, and he may make or issue orders and take any other action that he deems necessary or expedient for and incidental to the performance and execution of any duty, function or power imposed or conferred upon him by the Act and regulations for the purpose of oil and gas conservation."

It will be noted that the powers and authority of the Minister are rather general and wide. The reason for this is to give flexibility in administration in order that conservation legislation that deals with a comparatively young industry can readily adjust to changing conditions and rapidly developing technical and scientific knowledge and practices.

Unlike some of the other jurisdictions, such as Alberta, in Saskatchewan, the Minister of Mineral Resources is the administrative, executive, and, within the limits of the Act, the legislative authority. In keeping with the true spirit and principle of democracy, the Minister, as the elected representative of the people, is responsible and answerable to the electorate for his actions. Under Saskatchewan law, therefore, the Oil and Gas Conservation Board is an advisory board and it has no executive, administrative or legislative powers. However, since the Chairman of the Board is also the Deputy Minister of the Department, an executive link is maintained for administrative purposes.

I do not think that I should burden you with the detailed provisions of the Oil and Gas Conservation Act and the regulations, but I believe I should refer to the purposes of the Act is the basis for conservation legislation. The purposes of the Act are stated as follows: ${ }^{3}$

(a) to prevent waste;

(b) to regulate all operations for the production of oil and gas in such manner that the greatest possible ultimate recovery thereof by prudent and proper operations and practices may be realized;

(c) to protect the correlative rights of each owner; and

(d) to enable each owner to obtain his just and equitable share of the allowable production of any pool.

1 R.S.S. 1965, c. 360; O.C. 2272/68, effective January 1, 1969.

2 Id., s. 6 .

3 Id., s. 3. 
In the surveyed sedimentary area of Saskatchewan, the Crown in the right of Saskatchewan, owns over 70 per cent of the oil and gas rights and, as a major interest holder of actual and potential oil and gas reserves in Saskatchewan, the Crown is vitally concerned with the prevention of waste, conservation of valuable petroleum resources and protection of correlative rights of the owners of oil and gas. However, in the areas of oil and gas production an average of 50 per cent or greater is freehold. Understandably, therefore, the Oil and Gas Conservation Act applies to the Crown and Her Majesty is bound thereby and has the benefits thereof."

\section{The Oil and Gas Conservation Board of Saskatchewan}

In order to assist the Minister of Mineral Resources in the administration of the Act and regulations, the Lieutenant Governor in Council has established, under the authority of the Act, the Oil and Gas Conservation Board of Saskatchewan. ${ }^{5}$ The present Board consists of four members with the Deputy Minister of Mineral Resources as its chairman. By profession, the members of the Board include a professional engineer, a corporation lawyer with managerial experience with an oil company, a chartered accountant and a professor of geological sciences at the University of Saskatchewan. Any two members constitute a quorum for the transaction of business of the Board. All hearings of the Board are open to the public and all interested persons may be heard. ${ }^{\circ}$ The Board or any person authorized by it to make an inquiry or investigation has, for the purpose of the inquiry and investigation, all the powers conferred or that may be conferred upon commissioners under the Public Inquiries Act. ${ }^{7}$ The Board is an advisory board to the minister and not an administrative or legislative body. Its main function is to inquire into any matter referred to it by the Minister of Mineral Resources and to report to him thereon. ${ }^{8}$

In the past the Board has made inquiries and investigations by way of public hearings on such matters as:

(a) unit operations;

(b) statutory pooling;

(c) market proration;

(d) construction and operation of pipe lines;

(e) gas conservation projects;

(f) plans for pressure maintenance.

There is a provision in the Oil and Gas Conservation Act for any person who is affected by an order of the Minister without a recommendation by the Board, with or without a public hearing in respect of the matter to which the order relates, to apply for a Board hearing." Under this provision any matter of concern affecting any interested party may be brought under review so that there may not be any unilateral action of the Minister or the administrative agents of the minister without an appeal.

The Board has also participated in open and free discussions between the government and the oil and gas industry on matters of com-

\footnotetext{
4 Id., s. 4.

5 Id., s. 7 .

6 Id., s. 45 (2)

7 Id., s. 50.

8 Id., s. 48.

9 Id., s. 49.
} 
mon concern in the interest of public relations. Although the Minister is not legally bound to accept the findings of the Board or follow the recommendations of the Board in every case, the Minister has invariably recognized the expert knowledge, experience and wisdom of the Board and has never as yet rejected, set aside or overruled the Board or its recommendations. This truly democratic arrangement in which the appointed Board acts as a fact-finding, advisory body to the Minister, an elective representative, who is entrusted with the administrative and legislative powers within the purview of the Act, provides for happy flexibility and responsibility that stimulate active participation by small and large operators to compete in the search for oil and gas, and in obtaining a fair share of oil and gas from a common source of supply.

\section{Prevention of Waste}

In the unrestricted competitive development of an oil or gas pool where the rule of capture prevails, waste was of necessity inherent in the manner of production. Thus in the legislative field the first objective of an oil and gas conservation act should be prevention of physical waste. The Saskatchewan Act prohibits waste ${ }^{10}$ and every person who commits waste is guilty of an offence and liable on summary conviction to a fine not exceeding $\$ 10,000$ and in the case of a continuing offence to a further fine not exceeding $\$ 10,000$ for each day during which the offence continues." "Waste" is defined in the Act as follows:

(i) physical waste as that term is ordinarily understood in the oil and gas industry;

(ii) the inefficient, excessive or improper use of, or the dissipation of, reservoir energy;

(iii) the locating, spacing, drilling, equipping or operating of or producing from a well in a manner that causes, or is likely to cause, reduction in the quantity of oil or gas ultimately recoverable from a pool under prudent and proper operations and practices, or unnecessary or excessive surface loss of oil or gas;

(iv) the inefficient storage of oil or gas; or

$(v)$ the production of oil or gas in excess of transportation or marketing facilities or reasonable market demand. ${ }^{12}$

I have quoted at length the definition of waste because the term "prevention or prohibition of waste" as defined in the Act, is, in a nutshell, the essence of conservation. It will be noted that no mention is made of "economic waste." This omission is deliberate and wise. Economic waste implies price control and the determination by the administrative agency of economic limits, and except, perhaps, in the event of an emergency or public necessity, it is not considered to be in the best interest of healthy competition in a free enterprise economy to fix the economic limits of commodities such as oil and gas.

In fact we have our Combines Investigation Act and, in the United States, anti-trust laws which prohibit the fixing of prices of commodities and otherwise restraining competition in trade or commerce. On the other hand, it does not mean that economic considerations never enter into the application of conservation measures for any reasonable board has to have regard, in certain circumstances, to economics, which may have the effect of limiting the prevention of physical waste. But, at the same time, economics should not be the real motive for conservation.

\footnotetext{
10 Id., s. 53.

11 Id., s. 58

12 Id., s. 2 (p).
} 
Conservation legislation, therefore, to be effective and enforceable, must be reasonable and practicable and in the process, economics may play an important part. Be that as it may, prevention of reasonably avoidable waste is a public concern, as well as in the interest of the producers of oil and gas, and economic consideration is one means to that end in certain circumstances.

\section{Protection of Correlative Rights and Enabling Each Producer to Obtain \\ His Just and Equitable Share of the Allowable Production of a Pool}

In order to prevent physical waste it may be necessary to restrict the rate of production from a well in sufficient degree to permit proper and efficient use of the reservoir energy, or to prevent the excessive or premature dissipation of oil, gas or water that provides the displacing force of a reservoir, or to limit the production from a pool to market demand, or to shut in the well or convert it into an injection well for greater ultimate recovery. Such restriction, however, in order to be fair and reasonable, must concurrently provide for adequate protection of correlative rights of each individual owner of the oil and gas rights and give each producer the opportunity to obtain his fair share of the allowable production from a common source of supply.

These problems are created in the first instance because of the migratory nature of a substance like oil or gas. A fugacious substance, such as oil or gas, therefore, gives rise to a curious situation in which the oil or gas in place is physically undivided but the right to share in the oil or gas is legally divided. If, therefore, drilling a well into a producing reservoir is the only means of obtaining an owner's share of the oil or gas, neither waste can be prevented nor correlative rights of the separate owners of the tracts be protected.

Moreover, since regulatory action relating to conservation (such as drilling, well spacing, production allowables, water and gas penalties and unitization) must necessarily affect property rights and correlative rights of common owners of oil and gas in a pool, a conservation act or regulation must have due regard to the effect on property rights to the extent reasonably possible and consistent with the overriding public interest for the prevention of waste. For instance, to deny to the owner of a small or irregular shaped tract at the edge of a pool, the right to drill, because of certain spacing regulations, without providing a substitute right denies to him the opportunity to recover his fair share of the oil and gas in a pool.

The courts in the United States have held that a statute that prohibits the drilling of a well on less than an acre without providing a substitute right, other than voluntary pooling, is a denial of natural justice and therefore unconstitutional. Further, a Texas court has held that to grant to the owner of a small tract an allowable grossly and overly disproportionate to the recoverable reserves underlying his tract was equivalent to arbitrary confiscation of the oil and gas from other owners in the pool and therefore the allowable order was declared invalid. ${ }^{13}$

13 See the Normana case: Atlantic Refining Co. v. Railroad Commission (1961), 346 S.W. 2d 201, 14 O. \& G.R. 362; and the Port Acres case: Halbouty v. Railroad Commission (1962), 357 S.W. 2d 364, 16 O. \& G.R. 788. 
Saskatchewan's Act provides for such substitute right in the form of compulsory pooling ${ }^{14}$ and statutory unitization. ${ }^{15}$ Pooling or, in a larger scale, unitization, is the apportioning of oil or gas production among separately owned tracts comprising a spacing or drilling unit, or a pool or field or portion thereof, when it is not practicable to develop and operate independently the separate tracts in conformity with an established well spacing or unit operation or other development program for the greatest ultimate recovery of oil and gas.

The ideal situation is, of course, where pooling or unitization is effected by voluntary action with 100 per cent agreement. If, however, dependence is placed on agreement, any one or more of the separate owners of tracts in a reservoir can, regardless of his reasons, block a conservation program for the prevention of waste and for the greatest ultimate recovery. There are also other reasons for failure of voluntary units based on agreements, such as title difficulties, unknown, unascertainable or unlocatable owners and incompetent owners by virtue of mental incapacity or under age. Because of these reasons many proposed voluntary units can fail completely or be unduly delayed.

Some jurisdictions, such as the State of Mississippi, had adopted what is commonly known as equitable pooling or unitization. This device is not based upon a voluntary agreement of the owners nor is it based upon an order of a conservation authority compelling pooling or unitization. Equitable pooling or unitization arises from the fact of recognition, by both the conservation agency and the operator, of a unit in which there are separately owned tracts which have not been pooled or unitized by voluntary agreement. Although most of the cases on this matter dealt with drilling units, the doctrine of equitable pooling which was imposed by the courts as an equitable remedy for alleviating or correcting an injustice or encroachment of correlative rights was applied to allowable units, proration units and other unitized methods of operation. ${ }^{16}$

However, voluntary action and in some instances court action for instituting conservation programs and practices for preventing waste, achieving the greatest possible ultimate recovery and preserving correlative rights of the owners of oil and gas rights were often ineffective and inadequate. In addition to technical reasons of title difficulties, unknown or incompetent owners, etc., as previously stated, were reasons of human nature, resistance to change, lack of experience and foresight, greed and selfishness that often delayed or discouraged voluntary pooling and unitization as an equitable operational device for the most efficient and economic recovery of the maximum volume of oil and gas from a common pool.

Fortunately in Saskatchewan, the Oil and Gas Conservation Act provides for two types of pooling and unitization, namely:

(a) by voluntary agreement; ${ }^{17}$ and

(b) by an order of the Minister in the case of pooling, and of the Lieutenant Governor in Council in the case of unit operation, after a public hearing of the Oil and Gas Conservation Board. ${ }^{18}$

14 Supra, n. 1, ss. 30-33.

15 Id., ss. 34-43.

10 See 6 Williams \& Meyers, Oil and Gas Law \$ 906.

if Supra, n. 1, ss. 30 (1) and 43a.

is Id., ss. $30-33$ and 34-43. 
In the absence of voluntary pooling the Minister may, upon the application of any interested person, make an order for a Board hearing and, upon the recommendation of the Board, he may make an order pooling all interests within the drainage unit for the development and operation of such unit.

The Minister of Mineral Resources, upon his own motion, may, and upon the application of any interested person shall order that a public hearing be held by the Oil and Gas Conservation Board to consider the need for unit operation of an entire field or pool. Upon the recommendation of the Minister after such hearing, the Lieutenant Governor in Council may order that the field or pool or portion thereof be operated as a unit. The order must specify the effective date of the unit, the unit area, nature of the operation contemplated, an allocation among the separately owned tracts in the unit area of the net oil and gas produced, credits and charges in the adjustment of investments, provisions for expenses and capital investments to be charged to the separately owned tracts, provisions for appointing the operating committee and unit operator, voting procedure for carrying a motion of the operating committee, manner of terminating the unit and generally any other terms and conditions as may be considered necessary to provide for the operation of the unit in the interest of conservation. ${ }^{10}$

The production allocated to each separate tract under a unit order is deemed conclusively to have been actually produced from that tract and any operations conducted pursuant to the unit order are deemed to be operations for the production of oil and gas in the fulfilment of the express or implied obligations of the owner of the tract or of an operator under a mineral lease or other contract in so far as they relate to the unit. ${ }^{20}$ Under a unit order, therefore, each owner of the tracts constituting the unit is guaranteed, as nearly as practicable, a fair and equitable share of his oil or gas from a common source of supply. Waste is minimized and conservation achieved.

\section{Conclusion}

From the foregoing, it has become increasingly evident that in the public interest conservation, as a legislative and administrative function, is necessary and desirable and that there is a serious need for some modifications of the unrestricted rule of capture, the harsh technical and historical concepts of property law, unrestrained competitive operation and individual freedom to waste and encroach upon correlative rights of others. Conservation, therefore, as a method of regulation and its necessary administration, is perhaps one of public and political education and in the best interest of all concerned. 